\title{
BMJ Open Prevention of surgical site infection in lower limb skin lesion excisions with single dose oral antibiotic prophylaxis: a prospective randomised placebo- controlled double-blind trial
}

\author{
Samuel C Smith, ${ }^{1}$ Clare F Heal, ${ }^{2}$ Petra G Buttner ${ }^{3}$
}

To cite: Smith SC, Heal CF, Buttner PG. Prevention of surgical site infection in lower limb skin lesion excisions with single dose oral antibiotic prophylaxis: a prospective randomised placebo-controlled doubleblind trial. BMJ Open 2014;4: e005270. doi:10.1136/ bmjopen-2014-005270

- Prepublication history for this paper is available online. To view these files please visit the journal online (http://dx.doi.org/10.1136/ bmjopen-2014-005270).

Received 16 March 2014 Revised 22 June 2014 Accepted 27 June 2014

${ }^{1}$ The Townsville Hospital, Townsville, Queensland, Australia

${ }^{2}$ School of Medicine and Dentistry, James Cook University, Mackay, Queensland, Australia ${ }^{3}$ School of Public Health, Tropical Medicine and Rehabilitation Sciences, James Cook University, Townsville, Queensland, Australia

Correspondence to Dr Samuel C Smith; Samuel_Smith1@health.qld. gov.au

\section{ABSTRACT}

Objectives: To determine the effectiveness of a single perioperative prophylactic $2 \mathrm{~g}$ dose of cephalexin in preventing surgical site infection (SSI) following excision of skin lesions from the lower limb.

Design: Prospective double-blinded placebocontrolled trial testing for difference in infection rates.

Setting: Primary care in regional North Queensland, Australia.

Participants: 52 patients undergoing lower limb skin lesion excision.

Interventions: $2 \mathrm{~g}$ dose of cephalexin 30-60 min before excision.

Main outcome measures: Incidence of SSI.

Results: Incidence of SSI was $12.5 \%(95 \% \mathrm{Cl} 2.7 \%$ to $32.4 \%$ ) in the cephalexin group compared with $35.7 \%(95 \% \mathrm{Cl} 18.6 \%$ to $55.9 \%)$ in the placebo group $(p=0.064)$. This represented an absolute reduction of $23.21 \%(95 \% \mathrm{Cl}-0.39 \%$ to $46.82 \%)$, relative reduction of $65.00 \%(95 \% \mathrm{Cl}-12.70 \%$ to $89.13 \%)$ and number-needed-to-treat of 4.3 .

Conclusions: Administration of a single $2 \mathrm{~g}$ dose of cephalexin 30-60 min before skin lesion excision from the lower limb may produce a reduction in the incidence of infection; however, this study was underpowered to statistically determine this.

Trial registration number: ACTRN12611000595910.

\section{INTRODUCTION}

Skin cancer causes a significant burden of disease in many developed countries. ${ }^{12}$ The majority of skin cancers are treated by surgical excision ${ }^{3} 4$ which is increasingly being performed in outpatient and primary care settings..$^{5}$ As the majority of skin cancer surgery takes place in general practice in Australia, ${ }^{5}$ it is important to study infection rates in this setting. Skin lesion excisions form a large proportion of a typical Australian general practitioner's (GPs)

\section{Strengths and limitations of this study}

- Blinded randomised design with placebo control.

- Standardised protocol for excision and follow-up.

- Collection of a large amount of demographic, medical and excision-related data for comparison of groups.

- Underpowered study due to small sample size.

- Higher than anticipated infection rate with no clear underlying reason.

workload, and this proportion is even greater for Queensland GPs, given that this State has the highest incidence of skin cancer. ${ }^{6}$ General practice dermatological surgery may differ from a hospital setting, with most procedures taking place in treatment rooms rather than in formal operating theatres.

Surgical site infection (SSI) is one of the few complications of this relatively minor surgery. These infections often require antibiotics and repeat consultations to assess wound healing. They can potentially lead to significant bacteraemic complications and impair cosmetic outcome. ${ }^{7}$ The acceptable rate of infection following clean minor surgery (class 1 ) is less than $5 \% .^{8-12}$ This is reflected in skin lesion excisions, with a rate of between $1 \%$ and $3 \%$ in most studies. ${ }^{13-18}$ The exceptions are studies conducted by the present authors in 2005 and 2009 which reported infection rates of $8.6 \%$ and $11.7 \% .^{19}{ }^{20}$ The reason for this higher infection rate remains unclear, but might be related to tropical humidity. Even within cohorts with a low overall incidence of infection, some procedures may be at higher risk because of the body site, pathology or patient factors and infection rates may be greater than $5 \%$ in these high-risk groups. Previously identified risk factors include 
excisions from the region of the lower leg, ear and nose, ${ }^{1620-22}$ excisions of skin cancers ${ }^{2021}$ and excisions from patients with diabetes. ${ }^{20}$ In tropical North Queensland, the infection rates following excisions from the lower limb ranged from $14.75 \%$ to $18.18 \% .^{19} 20$ Several expert groups-including the Mayo Clinic's Department of Dermatological Surgery ${ }^{7} 23$-have suggested that a single oral dose of perioperative antibiotic prophylaxis may be indicated in certain 'high risk' situations such as excisions from the lower limb. If effective, this may be a low-cost and easily implemented method of reducing the incidence of SSI in selected situations. Recommendations such as these are however yet to be tested in clinical trials.

This trial sought to determine the efficacy of a $2 \mathrm{~g}$ dose of cephalexin given 30-60 min prior to skin lesion excision from the lower limb in preventing the subsequent development of an SSI.

\section{METHODOLOGY}

\section{Trial design}

We carried out a randomised double-blind placebocontrolled trial involving patients presenting for minor skin excisions from the lower limb.

\section{Setting and participants}

The study was conducted in two private general practices in Mackay, Queensland (latitude 21E8S; inhabitants $77293^{25}$ ) between September 2011 and May 2012. One of the participating practices was an open access designated skin cancer clinic which was run by two GPs specialising in skin cancer management. The other centre offered a full range of primary care services and all doctors working at the practice were involved in the study.

Consecutive patients presenting at either practice for a skin lesion excision from the lower limb were invited to participate. Exclusion criteria are shown in box 1. For patients having multiple excisions meeting inclusion criteria on the same or subsequent days, data were only analysed for the first excision conducted which met the inclusion criteria.

Demographic information was collected as well as clinical information about diabetes, anticoagulation and any

\section{Box 1 Exclusion criteria for participant recruitment}

$<18$ years old or not capable of providing informed consent Declined to participate.

Currently taking antibiotics or treating clinician feels they are clinically indicated for antibiotic treatment following excision.

Repair of lacerations or lesions considered as contaminated/ infected prior to surgery.

Excision not utilising primary closure (eg, shave biopsy or curette).

Excision of a sebaceous cyst.

Patient unable to return for suture removal.

Penicillin or cephalosporin allergy. other predetermined significant medical conditions. A body site map was used to record the excision site. At the end of the study, practice nurses were asked to re-examine computer records to fill in any missing data. The principal researcher visited participating GPs and practice nurses prior to the start of and regularly during the trial to ensure that data collection was standardised.

\section{Intervention and control}

The intervention arm of the trial consisted of a $2 \mathrm{~g}$ dose of cephalexin administered 30-60 min before an excision. The cephalexin (Keflex $500 \mathrm{mg}$ capsules) was compounded into generic gel capsules (SurgiPack Empty Gelatine Capsules, Size '00', $0.95 \mathrm{~mL}$ capacity). Rice flour was used to fill the placebo capsules as it had an identical appearance to the cephalexin powder and no foreseeable adverse effects. Each dose consisted of four capsules filled with either cephalexin or rice flour.

\section{Randomisation and blinding}

A computer-generated random number table was used to randomise a consecutive sequence of numbers into two groups-intervention and control-in permuted blocks of 20 with a 1:1 ratio. These numbers were used to label medicine jars containing the corresponding capsules. The content of the individual jar was known only to the principal researcher who had no direct involvement with participants or in data collection. All others involved in the trial were blinded to the capsule identity.

\section{Participant recruitment and trial protocol}

Eligible participants were identified by a practice nurse or doctor at the time of their pre-excision appointment. All patients provided signed consent before enrolling in the study. Participants were given a numbered medicine jar along with written and verbal instructions to take the four capsules 30-60 min before their excision appointment.

\section{Surgical wound management protocol}

Workshops were run at the participating practices to develop guidelines to ensure that excision management was standardised. The excision was performed using an aseptic technique and skin preparation with $2 \%$ chlorhexidine solution. Wounds were dressed with non-waterproof adhesive fabric dressings. Patients were provided with verbal and written instructions regarding wound care, including the need for wounds to be kept dry and covered for the first 2 days and for topical antiseptics or antibiotics not to be used. Time to removal of sutures (ROS) was 1216 days at the treating doctor's discretion.

\section{Outcome measures}

Wounds were assessed for infection by the practice nurse or doctor at the time of ROS, or sooner if patients re-presented earlier with a perceived infection. Our definition of SSI was based on the presence of any of the criteria shown in box 2. These were adapted from the 


\section{Box 2 Criteria for presence of a surgical site infection *}

Purulent discharge.

Erythema $>1 \mathrm{~cm}$ from the wound margin.

Localised swelling.

Patient reports increased tenderness at the wound site.

Patient reports increased heat at the wound site.

*Presence of any one or more of these criteria was deemed to represent the presence of a surgical site infection.

Centre for Disease Control and Prevention (CDC) definition for superficial SSI. ${ }^{26}$ Information was also collected on wound swabs performed, prescription of antibiotics and number of follow-up visits. Patients were asked about any adverse effects which could be attributed to the trial medication.

\section{Sample size}

Our sample size was calculated on the basis of previous studies ${ }^{19}{ }^{20}$ which predicted a baseline infection rate of $15 \%$ from the lower limb. We decided that an absolute reduction in the SSI rate of $10 \%$ or more would be clinically significant. To reach this conclusion with statistical that a sample size of 282 excisions would be required.

The trial was conducted as part of an honours research project which ran over a 2-year period. The decision was made to cease data collection once the desired sample size of 282 was collected or by May 2012 to allow time for completion of the honours thesis.

\section{Statistical methods}

Data were entered and stored in a Microsoft Access database and statistical analysis and tests conducted in IBM SPSS Statistics V.20. Numeric data were summarised using median values and IQRs. Categorical variables confidence (power $80 \%, \alpha$ error $5 \%$ ), it was calculated

were reported as proportions with Clopper-Pearson 95\% CIs calculated for incidence of infection.

Fisher's exact test was used to test the primary hypothesis; absolute and relative risk reductions were calculated with $95 \%$ CIs as well as the number-needed-to-treat (NNT). Comparison of other infection-related parameters, such as prescription of antibiotics and number of additional visits, was conducted with Fisher's exact test and Mann-Whitney U tests, respectively.

No provisions were made for an interim analysis as it was felt that there was low risk of potential harm.

\section{Ethics approval and trial registration}

The trial was registered on the Australian New Zealand Clinical Trials Registry (ACTRN: 12611000595910) prior to its start.

\section{RESULTS}

Of a total of 78 excisions from the lower limb conducted during the collection period, 26 cases were excluded from the study (figure 1). Fifty-two cases were subsequently randomised and underwent skin lesion excision. Three participants forgot to take the trial medication prior to their excision, and one participant treated his wound with a topical antiseptic. Follow-up was completed in all $52(100 \%)$ participants randomised. Six doctors across the two practices were involved, each recruiting between 3 and 18 patients.

\section{Baseline characteristics}

Comorbid conditions (excluding diabetes) were more common among those cases randomised to the cephalexin group compared with placebo $(87.5 \%$ vs $67.9 \%)$ and antihypertensive use was also higher $(70.8 \%$ vs

Figure 1 Trial profile (ROS, removal of sutures).

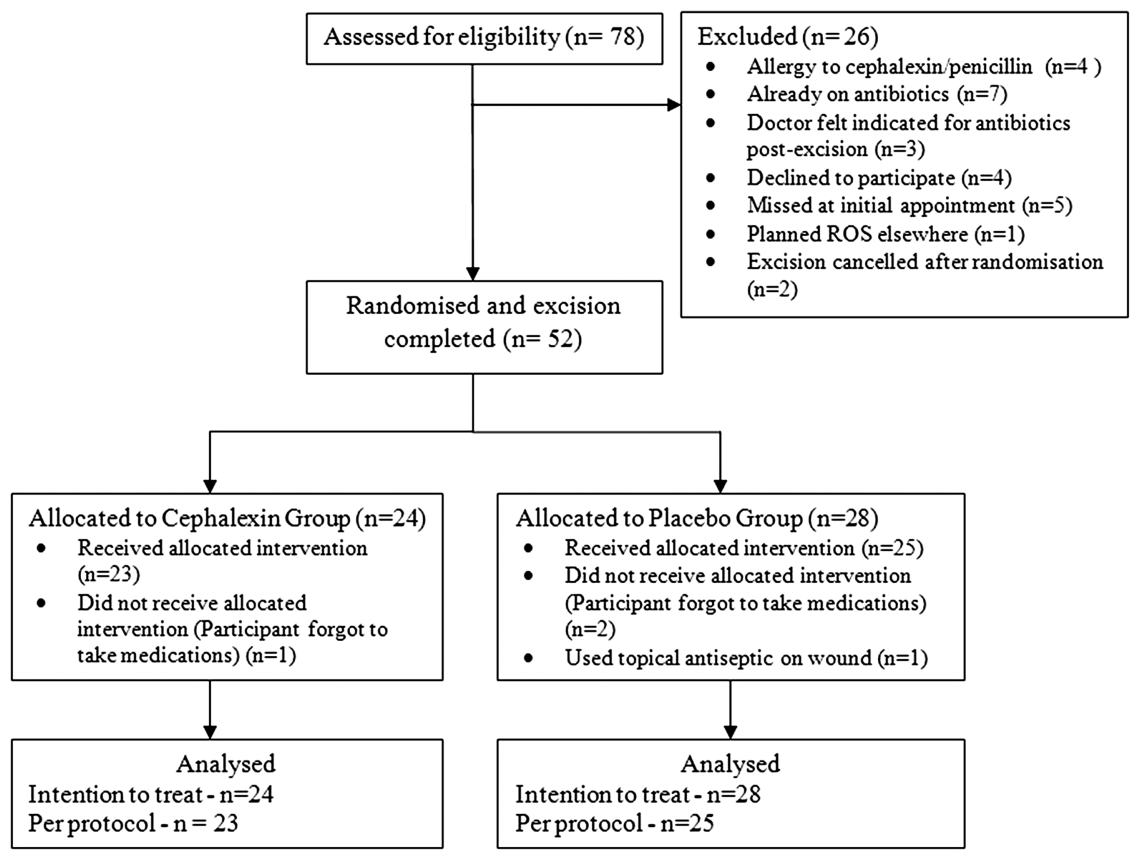




\section{Table 1 Baseline characteristics*}

\begin{tabular}{|c|c|c|}
\hline & Cephalexin $(n=24)$ & Placebo $(n=28)$ \\
\hline Male & $54.2(13)$ & $53.6(15)$ \\
\hline Retired & $58.3(14)$ & $60.7(17)$ \\
\hline Unemployed & $0(0)$ & $10.7(3)$ \\
\hline Working & $41.7(10)$ & $28.6(8)$ \\
\hline Ex-smoker & $50(12)$ & $35.7(10)$ \\
\hline Never smoked & $41.7(10)$ & $57.1(16)$ \\
\hline \multicolumn{3}{|l|}{ Alcohol consumption } \\
\hline Non-drinker & $45.8(11)$ & $32.1(9)$ \\
\hline Occasional (<1 day/week) & $16.7(4)$ & $21.4(6)$ \\
\hline Weekly & $37.5(9)$ & $39.3(11)$ \\
\hline Antihypertensive use & $70.8(17)$ & $50.0(14)$ \\
\hline Time from pill consumption to excision (min) & $61.5[50-75]$ & $60[48.25-65.75]$ \\
\hline Below knee & $83.3(20)$ & $82.1(23)$ \\
\hline Excision size (mm) & 22.5 [17.25-31.75] & 28.5 [22-36] \\
\hline \multicolumn{3}{|l|}{ Type of repair } \\
\hline Simple closure & $45.8(11)$ & $60.7(17)$ \\
\hline Two-layer closure & $50(12)$ & $32.1(9)$ \\
\hline Skin flaps & $4.2(1)$ & 7.1 (2) \\
\hline \multicolumn{3}{|l|}{ Histology } \\
\hline NMSC & $75.0(18)$ & $75.0(21)$ \\
\hline Melanoma & $4.2(1)$ & $3.6(1)$ \\
\hline Other benign & $21.4(6)$ & $29.2(7)$ \\
\hline
\end{tabular}

$50 \%)$. The median excision size was $6 \mathrm{~mm}$ smaller in the cephalexin group (table 1).

\section{Outcome measures and estimates}

The primary intention-to-treat analysis was conducted on all 52 cases which were randomised and in which the excision was performed (table 2). A secondary per protocol analysis was also performed that examined only cases where patients took their allocated trial medication and did not violate trial protocol (table 3).

In the intention-to-treat analysis, the incidence of SSI in the intervention group was $12.5 \%(3 / 24)$ compared with $35.7 \%(10 / 28)$ in the control group. This approached statistical significance $(\mathrm{p}=0.064)$, producing an absolute reduction of $23.21 \% \quad(95 \%$ CI $-0.39 \%$ to $46.82 \%)$, relative reduction of $65.00 \%(95 \%$ CI $-12.70 \%$ to $89.13 \%$ ) and an NNT of 4.3 .

There were also clinically relevant reductions in antibiotic prescriptions and follow-up visits. These were also not of statistical significance (table 2).
In the per protocol analysis, the difference in incidence of infection was statistically significant $(8.7 \%(2 / 23)$ vs $36 \%(9 / 25) ; p=0.039)$. The relative risk reduction for an SSI produced by prophylaxis was $75.85 \%(95 \% \mathrm{CI}-0.30 \%$ to $94.18 \%$ ), resulting in an absolute risk reduction of $27.30 \%$ (95\% CI $-3.50 \%$ to $51.10 \%$ ) and an NNT of 3.7 .

No adverse effects attributed to the trial medication were reported by participants.

\section{DISCUSSION}

In this trial, a $2 \mathrm{~g}$ dose of cephalexin 30-60 min before skin lesion excision from the lower limb was associated with a relative reduction in infection rate of $65 \%$ and an absolute reduction of $23.2 \%$ from a baseline infection rate of $35.7-12.5 \%$. Based on these findings, the NNT with prophylactic cephalexin was 4.31 in order to prevent one infection following excision from the lower limb. Additionally, prophylaxis resulted in a reduction in the number of therapeutic antibiotic courses required and number of follow-up visits. 
Table 2 Primary and secondary outcome measures intention-to-treat analysis*

\begin{tabular}{|c|c|c|c|c|}
\hline & Cephalexin $(n=24)$ & Placebo $(n=28)$ & Risk difference $(95 \% \mathrm{Cl})$ & p Value \\
\hline Number of infections & 3 & 10 & $0.35(0.11$ to 1.13$)$ & 0.064 \\
\hline Infection rate $(95 \% \mathrm{Cl})$ & $12.5(2.7$ to 32.4$)$ & 35.7 (18.6 to 55.9$)$ & NA & \\
\hline Prescription of antibiotics & 3 & 6 & $0.58(0.16$ to 2.09$)$ & 0.480 \\
\hline \multicolumn{5}{|c|}{ Number of additional follow-up visits required } \\
\hline Median & $0[0-0]$ & $0[0-1]$ & NA & 0.164 \\
\hline Total (Range) & $7(0-3)$ & $26(0-10)$ & NA & \\
\hline \multicolumn{5}{|c|}{ Additional total amount of antibiotics (excluding prophylaxis) $(\mathrm{mg}) \dagger$} \\
\hline Median & $0[0-0]$ & $0[0-0]$ & NA & 0.290 \\
\hline Total (Range) & $27000(0-12000)$ & $146750(0-66750)$ & NA & \\
\hline
\end{tabular}

\section{Limitations}

Although these findings met our predetermined level for clinical relevance, an absolute reduction of infection rate by $10 \%$, they were not statistically significant $(\mathrm{p}=0.064)$. Furthermore, a slower than predicted recruitment rate, and time constraints of the honours research project, resulted in the trial being terminated well before the calculated sample size was achieved. As such, this trial was unable to address the proposed hypothesis and no definitive conclusions can be drawn from it on the actual efficacy of antibiotic prophylaxis.

Various characteristics influence SSI and although information on as many variables as possible was recorded, it is difficult to ensure that all baseline data are comparable. Several characteristics did vary notably between the prophylaxis and placebo groups in this study. Given that the study was underpowered and did not achieve statistical significance, it was decided not to pursue adjustment for these imbalances using multiple logistic regression. Future studies, appropriately powered to address this hypothesis, will need to adjust for such baseline difference as well as consider cluster analysis based on individual GPs to limit the confounding effect on variable training, experience and outcomes among practitioners.
Even when using guidelines, the diagnosis of infection is still subjective and there may be interobserver and intraobserver variation. ${ }^{27}$ The 1992 CDC definition of SSI that we chose to use has limitations. However, it is the most widely implemented standard definition of wound infection $^{27}$ and is the closest to a gold standard available. We have no evidence to support intrapractice and interpractice reproducibility of measurement and recording procedures. This is also an area which future studies may consider addressing.

\section{Generalisability}

The baseline infection rate for lower limb excisions in this trial was considerably higher than that reported in other studies, including those previously conducted in Mackay. ${ }^{19} 20$ The underlying reason for this is uncertain, but may be related to the majority of the excisions being from below the knee, a site that has previously been identified as being at an even higher risk of infection. Furthermore, the infection rate in studies conducted in Mackay has consistently been higher than that reported in other centres. This further adds to the argument that climate/environmental factors may be important determinants of SSI following skin lesion excision. Owing to the higher than expected infection rate, there

Table 3 Primary and secondary outcome measures per protocol analysis*

\begin{tabular}{|c|c|c|c|c|}
\hline & Cephalexin $(n=23)$ & Placebo $(n=25)$ & Risk difference (95\% Cl) & p Value \\
\hline Number of infections & 2 & 9 & 0.24 (0.06 to 1.00$)$ & 0.039 \\
\hline Infection rate $(95 \% \mathrm{Cl})$ & 8.7 (1.1 to 28.0$)$ & 36.0 (18 to 57.5$)$ & NA & \\
\hline Prescription of antibiotics & $2(8.7 \%)$ & $6(24.0 \%)$ & $0.36(0.08$ to 1.62$)$ & 0.249 \\
\hline \multicolumn{5}{|c|}{ Number of additional follow-up visits required } \\
\hline Median & $0[0-0]$ & $0[0-1]$ & NA & 0.058 \\
\hline Total & 5 & 26 & NA & \\
\hline
\end{tabular}

$95 \% \mathrm{Cl}$ for infection rates are the Clopper-Pearson interval.

${ }^{*}$ Data are median [IQR] or number (\%) unless otherwise stated; $95 \% \mathrm{Cl}$ for infection rate are the Clopper-Pearson interval; $p$ values are Fisher's exact test or the Mann-Whitney $U$ test for categorical and continuous variables, respectively.

NA, not available. 
Table 4 Studies of systemic antibiotic prophylaxis for skin lesion excision

\begin{tabular}{|c|c|c|c|c|}
\hline $\begin{array}{l}\text { Study, } \\
\text { country }\end{array}$ & $\begin{array}{l}\text { Setting and } \\
\text { sample size }\end{array}$ & Intervention and control & Wound type & $\begin{array}{l}\text { Infection rate } \\
\text { (relative reduction) }\end{array}$ \\
\hline $\begin{array}{l}\text { Amland } \\
\text { et al, } \\
\text { Norway }\end{array}$ & $\begin{array}{l}\text { Plastic surgery } \\
\text { unit, } 60 \text { patients }\end{array}$ & $\begin{array}{l}\text { Control: placebo } \\
\text { Intervention: single dose } 1000 \mathrm{mg} \\
\text { orally azithromycin the night before } \\
\text { surgery }\end{array}$ & Skin cancer surgery & $\begin{array}{l}\text { Control: } 16.0 \% \\
\text { Azithromycin: } 5.7 \% \\
(0.36)\end{array}$ \\
\hline $\begin{array}{l}\text { Bencini } \\
\text { et } a{ }^{29},{ }^{29} \text { Italy }\end{array}$ & $\begin{array}{l}\text { Outpatient } \\
\text { dermatologic } \\
\text { surgery unit, } \\
527 \text { patients }\end{array}$ & $\begin{array}{l}\text { A: no prophylaxis } \\
\text { B: } 1 \mathrm{~g} \text { intramuscular cefazolin } 12 \\
\text { hourly for } 48 \mathrm{~h} \text { before and after } \\
\text { surgery } \\
\mathrm{C}: 1 \mathrm{~g} \text { intramuscular cefazolin } 12 \\
\text { hourly from } 2 \mathrm{~h} \text { before surgery to } 24 \mathrm{~h} \\
\text { after } \\
\mathrm{D} \text { : single } 1 \mathrm{~g} \text { intramuscular dose } \\
\text { cefazolin } 2 \mathrm{~h} \text { before surgery }\end{array}$ & $\begin{array}{l}\text { Excisions from } \\
\text { contamination- prone areas } \\
\text { (groin, axillae, interdigital } \\
\text { spaces of feet) }\end{array}$ & $\begin{array}{l}\text { A: } 12 \% \\
\text { B: } 4.6 \%(0.38)^{\star} \\
\text { C: } 0.77 \%(0.064)^{\star} \\
\text { D: } 2 \%(0.17)^{\star}\end{array}$ \\
\hline $\begin{array}{l}\text { Czarnecki } \\
\text { et al, } \\
\text { Australia }\end{array}$ & $\begin{array}{l}\text { Outpatient } \\
\text { dermatology } \\
\text { clinic, } \\
97 \text { lesions }\end{array}$ & $\begin{array}{l}\text { Intervention } 1: 500 \mathrm{mg} \text { orally } \\
\text { cephalexin three times a day, starting } \\
2 \text { days before and continuing } 24 \mathrm{~h} \\
\text { postoperatively } \\
\text { Intervention } 2 \text { : topical mupirocin three } \\
\text { times a day from } 2 \text { days before and } \\
\text { continuing } 24 \mathrm{~h} \text { postoperatively } \\
\text { Control: cetrimide-chlorhexidine cream } \\
2 \text { days before and continuing } 24 \mathrm{~h} \\
\text { postoperatively }\end{array}$ & $\begin{array}{l}\text { Ulcerated skin cancers which } \\
\text { cultured positive for } \\
\text { Staphylococcus aureus or } \\
\text { Gram-negative bacteria }\end{array}$ & $\begin{array}{l}\text { Control: } 21.7 \% \\
\text { Intervention } \\
1: 2.7 \%(0.12)^{\star} \\
\text { Intervention } \\
2: 0 \%(0)^{\star}\end{array}$ \\
\hline $\begin{array}{l}\text { Bencini } \\
\text { et } a{ }^{31}{ }^{31} \text { Italy }\end{array}$ & $\begin{array}{l}\text { Outpatient } \\
\text { dermatologic } \\
\text { surgery unit, } \\
2165 \text { patients }\end{array}$ & $\begin{array}{l}\text { A: no antibiotic } \\
\text { B: } 1 \mathrm{~g} \text { intramuscular cefazolin } 12 \\
\text { hourly immediately after surgery } \\
\text { continuing for } 3 \text { days } \\
\text { C: } 250 \mathrm{mg} \text { cefazolin powder applied } \\
\text { locally during surgery } \\
\text { D: } 1 \mathrm{~g} \text { cefazolin intramuscular } 12 \\
\text { hourly starting } 2 \text { days before and } \\
\text { continuing } 2 \text { days after surgery }\end{array}$ & Excision of skin lesions & $\begin{array}{l}\text { A: } 4.3 \% \\
\text { B: } 1.5 \%(0.35)^{\star} \\
\text { C: } 0.9 \%(0.21)^{\star} \\
\text { D: } 0.2 \%(0.047)^{\star}\end{array}$ \\
\hline
\end{tabular}

may be limitations to extrapolating these results to other centres, where the baseline infection is lower. However, similar relative reductions have been produced with prophylactic regimens, including single dose parenteral antibiotics, in settings with lower baseline infection rates (table 4).

Antibiotic prophylaxis is probably prescribed excessively or inappropriately for dermatological surgery and is thought to be best reserved for high-risk patients such as excisions from the lower limb. ${ }^{7} 23{ }^{24}$ There are no data available on the current prescribing habits of Australian GPs regarding oral prophylaxis for minor excisions. The decision to prescribe antibiotic prophylaxis is complicated; in addition to efficacy, antibiotic costs, adverse effects and resistance must also be taken into account.

The role of antibiotic prophylaxis in the prevention of SSI following skin lesion excision remains controversial. ${ }^{32}$ Randomised trials have demonstrated that topical antibiotic prophylaxis is ineffective and should not be used. $^{33} 34$ Infusion of antibiotic mixed with local anaesthetic, and systemic prophylactic regimes, have produced significant reductions in infection rates. ${ }^{31} 293536$ The limited available literature has demonstrated comparable relative reductions in SSI to this study (table 4). ${ }^{28-31}$ Two of these studies examined the use of oral prophylaxis ${ }^{28} 30$ while the other two considerably larger studies examined various regimens of intramuscular cefazolin. ${ }^{3129}$ With the exception of Amland et $a l^{28}$ and one arm of the 1994 study by Bencini et $a l,{ }^{29}$ all of these studies examined short courses of prophylaxis rather than single doses. Although variations in the study populations and protocols make comparison difficult, the reductions achieved in this study appear to be at least similar to those achieved with short courses of prophylaxis and parenteral methods of delivery.

\section{CONCLUSION}

In this study, a $2 \mathrm{~g}$ dose of cephalexin 30-60 min before skin lesion excisions from the lower limb was associated with a reduced risk of SSI from $35.7 \%$ to $12.5 \%$, 
producing an absolute reduction of $23.2 \%$, a relative reduction of $65 \%$ and an NNT of 4.3 . This reduction, however, was not statistically significant $(\mathrm{p}=0.064)$, and the trial was underpowered to address the hypothesis. As such, no definitive conclusion can be drawn on the efficacy of oral prophylaxis for lower limb skin lesion excision from this trial. Given the potential benefits, further investigation is warranted.

Acknowledgements The authors thank Ms Laurie, Ms Robyn Cavanagh, Ms Debbie Kimber, Ms Tracy Maloney, Ms Julie O'Sullivan, Ms Catherine Weiske, Dr Sheldon Browning, Dr Andrea Cosgrove, Dr AllisonDischer, Dr Luke Notely, Dr O'Neill, Dr Lutie Van den Berg and PHCRED Townsville.

Contributors SCS established and oversaw the study design and implementation, compiled the data and conducted the primary analysis. CFH conceived the study idea, identified suitable practices and assisted in study design and analysis. PGB assisted in sample size calculation and study analysis. All authors contributed to manuscript production.

Funding This study was funded jointly through funds available from the James Cook University Honours programme and CFH's University Research account and through general funds available to $\mathrm{CFH}$ from the Primary Health Care Research and Information Service for primary care research in Mackay.

Competing interests None.

Ethics approval James Cook University Human Research Ethics Committee.

Provenance and peer review Not commissioned; externally peer reviewed.

Data sharing statement Extra data can be accessed via the Dryad data repository at http://datadryad.org/ with the doi:10.5061/dryad.k3r47.

Open Access This is an Open Access article distributed in accordance with the Creative Commons Attribution Non Commercial (CC BY-NC 4.0) license, which permits others to distribute, remix, adapt, build upon this work noncommercially, and license their derivative works on different terms, provided the original work is properly cited and the use is non-commercial. See: http:// creativecommons.org/licenses/by-nc/4.0/

\section{REFERENCES}

1. Diepgen $\mathrm{TL}$, Mahler V. The epidemiology of skin cancer. $\mathrm{Br} \mathrm{J}$ Dermatol 2002;146(Suppl 61):1-6.

2. Lens MB, Dawes M. Global perspectives of contemporary epidemiological trends of cutaneous malignant melanoma. $\mathrm{Br} J$ Dermatol 2004:150:179-85.

3. Cancer Council Australia and Australian Cancer Network. Basal cell carcinoma, squamous cell carcinoma (and related lesions) - A guide to clinical management in Australia. 2008.

4. Australian Cancer Network Melanoma Guidelines Revision Working Party. Clinical practice guidelines for the management of melanoma in Australia and New Zealand. Wellington: Cancer Council Australia and Australian Cancer Network, Sydney and New Zealand Guidelines Group, 2008.

5. Askew DA, Wilkinson D, Schluter PJ, et al. Skin cancer surgery in Australia 2001-2005: the changing role of the general practitioner. Med J Aust 2007;187:210-14.

6. Del Mar CB, Lowe JB. The skin cancer workload in Australian general practice. Aust Fam Physician 1997;26(Suppl 1):S24-7.

7. Wright TI, Baddour LM, Berbari EF, et al. Antibiotic prophylaxis in dermatologic surgery: advisory statement 2008. J Am Acad Dermatol 2008;59:464-73.

8. Culver DH, Horan TC, Gaynes RP, et al. Surgical wound infection rates by wound class, operative procedure, and patient risk index. National Nosocomial Infections Surveillance System. Am J Med 1991;91(3B):152S-57S.

9. Haas AF. Antibiotic prophylaxis. Semin Dermatol 1994;13:27-34.
10. Cruse PJ, Foord R. The epidemiology of wound infection. A 10-year prospective study of 62,939 wounds. Surg Clin North Am 1980;60:27-40.

11. Cho CY, Lo JS. Dressing the part. Dermatol Clin 1998;16:25-47.

12. Haas AF, Grekin RC. Antibiotic prophylaxis in dermatologic surgery. J Am Acad Dermatol 1995;32(2 Pt 1):155-76; quiz 77-80.

13. Dixon AJ, Dixon MP, Dixon JB. Prospective study of skin surgery in patients with and without known diabetes. Dermatol Surg 2009;35:1035-40.

14. Dixon AJ, Dixon MP, Askew DA, et al. Prospective study of wound infections in dermatologic surgery in the absence of prophylactic antibiotics. Dermatol Surg 2006;32:819-26.

15. Whitaker DC, Grande DJ, Johnson SS. Wound infection rate in dermatologic surgery. J Dermatol Surg Oncol 1988;14:525-8.

16. Futoryan T, Grande D. Postoperative wound infection rates in dermatologic surgery. Dermatol Surg 1995;21:509-14.

17. Gabrielli F, Potenza C, Puddu P, et al. Suture materials and other factors associated with tissue reactivity, infection, and wound dehiscence among plastic surgery outpatients. Plast Reconstr Surg 2001;107:38-45.

18. Dettenkofer M, Wilson C, Ebner W, et al. Surveillance of nosocomial infections in dermatology patients in a German university hospital. $\mathrm{Br}$ J Dermatol 2003;149:620-3.

19. Heal C, Buettner $P$, Drobetz $H$. Risk factors for surgical site infection after dermatological surgery. Int J Dermatol 2012;51:796-803.

20. Heal C, Buettner P, Browning S. Risk factors for wound infection after minor surgery in general practice. Med J Aust 2006;185:255-8.

21. Sylaidis P, Wood S, Murray DS. Postoperative infection following clean facial surgery. Ann Plast Surg 1997;39:342-6.

22. Lathlean S. Skin cancer in general practice in South Australia. A five year study. Aust Fam Physician 1999;28(Suppl 1):S28-31.

23. Moorhead C, Torres A. I PREVENT bacterial resistance: an update on the use of antibiotics in dermatologic surgery. Dermatol Surg 2009;35:1532-8.

24. Rosengren H, Dixon A. Antibacterial prophylaxis in dermatologic surgery: an evidence-based review. Am J Clin Dermatol 2010;11:35-44.

25. Australian Bureau of Statistics. 2011 Census QuickStats: MackaySignificant Urban Area (Code 3010), Last Revised 28th March 2013, viewed 03 September 2013. http://www.censusdata.abs.gov.au/ census services/getproduct/census/2011/quickstat/3010? opendocument\&navpos $=220 \mathrm{e}$

26. Mangram AJ, Horan TC, Pearson ML, et al. Guideline for prevention of surgical site infection, 1999. Centers for Disease Control and Prevention (CDC) hospital infection control practices advisory committee. Am J Infect Control 1999;27:97-132.

27. Bruce J, Russell EM, Mollison J, et al. The quality of measurement of surgical wound infection as the basis for monitoring: a systematic review. J Hosp Infect 2001;49:99-108.

28. Amland PF, Andenaes $\mathrm{K}$, Samdal $\mathrm{F}$, et al. A prospective, double-blind, placebo-controlled trial of a single dose of azithromycin on postoperative wound infections in plastic surgery. Plast Reconstr Surg 1995;96:1378-83.

29. Bencini PL, Signorini M, Galimberti M, et al. Preoperative antibiotic prophylaxis in flexural surgery of difficult contamination-prone areas of the skin: The utility of a single dose of antibiotic. $J$ Dermatolog Treat 1994;5:17-19.

30. Czarnecki D, Meehan C, Nash C. Prevention of post-excisional wound infections: a comparison of oral cephalexin with topical mupirocin and topical cetrimide-chlorhexidine cream. Int J Dermatol 1992;31:359-60.

31. Bencini PL, Galimberti M, Signorini M, et al. Antibiotic prophylaxis of wound infections in skin surgery. Arch Dermatol 1991;127:1357-60.

32. Shurman DL, Benedetto AV. Antimicrobials in dermatologic surgery: facts and controversies. Clin Dermatol 2010;28:505-10.

33. Smack DP, Harrington AC, Dunn C, et al. Infection and allergy incidence in ambulatory surgery patients using white petrolatum vs bacitracin ointment. A randomized controlled trial. JAMA 1996;276:972-7.

34. Dixon AJ, Dixon MP, Dixon JB. Randomized clinical trial of the effect of applying ointment to surgical wounds before occlusive dressing. Br J Surg 2006:93:937-43.

35. Griego RD, Zitelli JA. Intra-incisional prophylactic antibiotics for dermatologic surgery. Arch Dermatol 1998;134:688-92.

36. Huether MJ, Griego RD, Brodland DG, et al. Clindamycin for intraincisional antibiotic prophylaxis in dermatologic surgery. Arch Dermatol 2002:138:1145-8. 